\title{
Complex innovations in agriculture, environment, and health - the perceptions of rice farmers in the Jequetepeque Valley, Peru
}

\author{
Inovações complexas em agricultura, meio ambiente e \\ saúde - as percepções de produtores de arroz do Vale \\ do Jequetepeque, Peru \\ Renata Távora ${ }^{1}$ \\ José Augusto Drummond ${ }^{2}$ \\ Alain Santandreu ${ }^{3}$ \\ Anita Luján ${ }^{4}$ \\ Ernesto Ráez-Luna ${ }^{5}$ \\ Ester Montalvan ${ }^{6}$ \\ Elena Ogusuko ${ }^{7}$ \\ Frédéric Mertens ${ }^{8}$
}

${ }^{1}$ PhD in Sustainable Development, Researcher, INCT-ODISSEIA, Universidade de Brasília, Brasilia, Brazil E-mail: renata.tavora@gmail.com

${ }^{2}$ PhD in Land Resources, Professor, Centro de Desenvolvimento Sustentável, Universidade de Brasília, Brasília, Brazil E-mail: jaldrummond@uol.com.br

${ }^{3}$ Graduate in Sociology, Executive Director, Consorcio por la Salud, Ambiente y Desarrollo (Ecosad), Lima, Peru E-mail: alain.santandreu@gmail.com

${ }^{4}$ Graduate in Nursing, Professor, Universidad Nacional Mayor de San Marcos, Lima, Peru E-mail: alujang@unmsm.edu.pe

${ }^{5}$ Master in Latin American Studies, Executive Director, Instituto del Bien Común, Lima, Peru E-mail: eraez@ibcperu.org

${ }^{6}$ Bachelor of Social Sciences, Social Facilitator, Inerco, Piura, Ayabaca, Peru E-mail: montalvan.ts@hotmail.com

${ }^{7}$ Bachelor in Biology, Dirección General de Salud Ambiental e Inocuidad Alimentaria, Ministerio de Salud, Lima, Peru E-mail: elenaoa2013@gmail.com

${ }^{8}$ PhD in Environmental Sciences, Professor, Centro de Desenvolvimento Sustentável, Universidade de Brasília, Brasília, DF, Brazil E-mail: mertens.br@gmail.com 


\section{ABSTRACT}

The increased use of water in irrigated rice monocultures in the Jequetepeque Valley, on the northern coast of Peru, has exacerbated environmental, socioeconomic and health problems. The Alternate Wetting and Drying (AWD) irrigation technique aims to increase water management efficiency in rice cultivation. The objective of the present article is to understand farmers' perceptions about the benefits and risks of implementing AWD. Data from interviews with 319 farmers showed that they recognise nine interactions between AWD's economic, environmental and health aspects but prioritise economic factors when assessing its benefits. We also identified the main channels and spaces of communication and debate on issues related to agriculture and health that are likely to be effective in promoting the diffusion of AWD. The study demonstrated the relevance of integrated actions to encourage the adoption of agricultural innovations which consider the interactions between environmental sustainability, health issues, and producers' economic priorities.

Keywords: Diffusion of innovations. Agriculture. Rice. Intermittent irrigation. Malaria. Sustainability.

\section{RESUMO}

O aumento do uso de água nas monoculturas de arroz irrigado do Vale do Jequetepeque (costa norte do Peru) vem agravando problemas ambientais, socioeconômicos e de saúde. Nesse contexto, a Técnica de Irrigação com Secas Intermitentes (Tisi) oferece uma oportunidade de manejo mais eficiente da água no cultivo do arroz. O presente artigo buscou compreender as percepções dos agricultores sobre os benefícios e riscos do uso da Tisi. Dados de entrevistas com 319 agricultores mostraram que eles reconhecem as interações entre os aspectos econômicos, ambientais e de saúde, mas priorizam as questões econômicas para avaliar os benefícios da Tisi. Identificamos também os canais e espaços de comunicação privilegiados sobre os temas de agricultura e saúde com potencial de promover a difusão da Tisi. O estudo demonstrou a relevância de ações integradas para promover a adoção de inovações agrícolas, que considerem as interações entre sustentabilidade ambiental, questões de saúde e prioridades econômicas dos produtores.

Palavras-chave: Difusão de inovações. Agricultura. Arroz. Irrigação intermitente. Malária. Sustentabilidade.

\section{INTRODUCTION}

Water availability in the Jquetepeque Valley, located on the northern coast of Peru, has been gradually diminishing in the last decades. This is mainly due to a rice monoculture system with permanent irrigation, which is standard in the region. The entire northern coast is emblematic in its geo-climatic conditions and has been suffering for millennia with extreme and adverse events - sometimes prolonged droughts, sometimes exceptional rain - that produce generalised effects such as dune formation and desertification, as well as great floods along coastal rivers (GIRALT et al., 2007; RODRÍGUEZ-MORATA et al., 2019). Considering this scenario, agriculture is one of the productive activities that is most threatened by climate change, creating uncertainty and economic instability for the farmers in the region (PERU, 2016).

Permanent flood irrigation generates other problems contributing to farmers' vulnerability in the valley, such as increasing vector-borne diseases, including malaria (GUTHMANN et al., 2002). The condition is considered endemic in the region, and its control requires preventive measures, given the direct relation between irrigated agriculture and the proliferation of mosquito vectors (IBARGÜEN, 2019). In this sense, adopting more sustainable cultivation and irrigation practices may contribute to an agricultural production that is more efficient in economic terms, is less vulnerable to climate change, and presents fewer risks and damages to the environment and farmers' health families. 
In 2014, the Peruvian Ministry of Health initiated a research and intervention to analyse the feasibility of the Alternate Wetting and Drying (AWD) irrigation technique to promote sustainability in rice production in the Jequetepeque valley. This practice was developed in Asia around 300 years ago. However, it is only in the last four decades that it has been systematised by international research groups and spread to other continents and countries, including Peru (KEISER; UTZINGER; SINGER, 2002; PERU, 2002). The technique consists of more efficient irrigation management in rice cultivation through controlled drought periods as a substitute for permanent flooding. AWD is considered a complex innovation because of its implications in many dimensions such as (i) socioeconomic, due to reduction in production cost; (ii) environmental, due to adequate water management and soil protection; and (iii) health, due to the reduction of habitat for the disease vector mosquitoes (PERU, 2012).

Rice farmers have not broadly adopted AWD on the northern Peruvian coast despite scientific evidence on socioeconomic, environmental, and health impacts. Understanding farmers' perceptions of the benefits and risks of implementing AWD is essential to addressing opportunities and challenges to its adoption on a large scale. This article aims to understand factors that can favour or hinder AWD implementation from the perception of rice farmers in the Jequetepeque valley on its socioeconomic, environmental, and health character following.

The following section presents a revision of scientific evidence on AWD benefits and limitations and factors frequently associated with perceptions of agricultural innovations.

\subsection{ALTERNATE WETTING AND DRYING IRRIGATION TECHNIQUE (AWD)}

In the last four decades, many research groups and international agencies have systematised alternative practices of rice cultivation that integrate the control of different irrigation regimes, also called water-saving techniques or water-saving technology (HUMPHREYS et al., 2005). The practices seek to reduce water usage in irrigation and increase efficiency in its use without compromising productivity. One of these technologies is the Alternate Wetting and Drying irrigation technique (AWD), also known as intermittent irrigation.

A significant number of studies conducted in many countries has consolidated a robust knowledge on AWD, describing its many benefits and limitations (ENRIQUEZ et al., 2021). In Peru, studies performed since the 2000s have had an integrated focus on economic and health aspects, including the environmental dimension, as well as a solid participative content with strategies for political diffusion, communication, and regulation on rice cultivation in the country (CHÁVEZ, 2007; PERU, 2002, 2011, 2012; VÉLEZ, 2008). Hence, AWD can be characterised by its multidimensional properties that intervene simultaneously on socioeconomic, environmental, and health factors.

Previous research points to many socioeconomic benefits in implementing intermittent irrigation regimes in rice cultivation (ALEN; SANDER, 2019). In the northern coast of Peru, studies showed that AWD increased productivity per hectare by $20-25 \%$, allowing less competition for resources between farmers (CHÁVEZ, 2007; PERU, 2002). Also, Awa D can reduce production costs, as it improves water usage efficiency and reduces expenses with irrigation, which are generally included in rice cultivation output calculation (ALAUDDIN et al., 2020). An AWD validation study in Peru in 2006, made by the Ministry of Health in a district close to the Jequetepeque valley, verified a $35 \%$ irrigation water saving per hectare (PERU, 2011).

On the other hand, the AWD application also presents some negative implications in the economic realm. One of them is the need to control weeds and other diseases that arise when there is no continuous irrigation (ISHFAQ et al., 2020). This generates an increase in labour costs to manage and remove these pests. However, some adjustments may bypass this problem, such as combining preemergent herbicides with shallow water for 10 to 15 days after transplant. This method may delay the crops' drying period, but helpful to control weeds as it increases herbicide efficacy and allows the plant to recover from transplantation shock (MUBEEN; JABRAN, 2019). 
In the environmental dimension, research shows the significant contributions of AWD in diminishing the main environmental impacts related to rice cultivation. Permanently irrigated crops are an essential source of methane $\left(\mathrm{CH}_{4}\right)$, one of the leading gases of the Greenhouse Gas Effect (GGE), and contributes to $10 \%$ of global agricultural emission of $\mathrm{CH}_{4}$ (ENRIQUEZ et al., 2021). Due to more rigorous control of volumes of water for irrigation, AWD can reduce $\mathrm{CH}_{4}$ emissions by $48-93 \%$. Other studies analysed the reduction of nitrous oxide $\left(\mathrm{N}_{2} \mathrm{O}\right)$ emissions, another type of GGE emitted by rice crops, due to excessive nitrogen fertilisers (BALAINE et al., 2019). Also, AWD allowed for a natural correction of nutritional deficiencies in the soil with the increased microbial and macrofauna (worms and other invertebrates) that resurge in aerobic conditions, stimulating organic nutrient cycling (ALEN; SANDER, 2019).

The monitoring of irrigation regimes also reduces soil degradation produced by nutrient leaching and by salinisation. Traditional irrigation makes the salt found in the soil come to the surface, reducing crop productivity (GORDON; FINLAYSON; FALKENMARK, 2010). The application of AWD reduces saturation in these fields and soil fertility problems (HUMPHREYS et al., 2005).

Rice monoculture is highly dependent on external input and agrochemicals, like chemical fertilisers, insecticides, fungicides, and herbicides, that provoke generalised contamination of ecosystems and increase health risks for workers (MACHER; LUNA, 2016). Many studies have described that AWD can reduce environmental contamination and human exposure because it adopts more selective criteria to use these products (ALEN; SANDER, 2019).

Regarding health, AWD has as its main benefit the reduction of vector-borne diseases, due to the elimination of habitat for mosquitoes that are vectors of malaria (Anopheles albimanus) and other diseases, as well as the Aedes aegypti (transmits dengue fever, yellow fever, chikungunya fever, and zika virus), and the Culex spp (vector to many viral encephalitis) (KEISER; UTZINGER; SINGER, 2002). Studies in the northern Peruvian coast showed that AWD considerably reduced (between 86 and 93\%) the larvae of malaria-transmitting mosquito (CHÁVEZ, 2007; PERU, 2002, 2011, 2012).

Despite economic, environmental, and health benefits, successful implementation of AWD depends on other factors and local conditions, which interact with the innovation's characteristics and influence farmers' perspectives. Next, we will present many categories of relevant factors to understand farmers' perceptions of agricultural innovations.

\subsection{FACTORS ASSOCIATED WITH PERCEPTION OF AGRICULTURAL INNOVATIONS}

The process of adopting new ideas, practices, or behaviours in agricultural production is conditioned to a series of factors that can influence farmers' perception of the benefits and risks of these innovations (ROGERS, 2003). Three broad categories of factors are recognised as able to affect perceptions and the adoption of agricultural innovation (MEIJER et al., 2015):

I. characteristics of farmers, that is, their socio-demographic profiles, their performances in collective spaces of political decisions and associativism, and knowledge and experience acquired in their productive contexts and about their environmental and health issues;

II. characteristics of the productive system, which includes information on the land, cultivation modes, and production costs; and

III. communication channels, formal and informal, which gather the many sources of information used by farmers on relevant themes for their agricultural production. 
Next, we detail these three groups of factors, focusing on their relevance to farmers' perceptions of AWD in the Jequetepeque valley.

\subsubsection{CHARACTERISTICS OF FARMERS}

There is growing recognition of the importance of understanding gender roles in forming perceptions on complex innovations that involve multiple dimensions: socioeconomic, environmental, and health. Differences in interests, experiences, and culturally sanctioned functions to men and women in a given social context result in different decisions and behaviours on many themes (SAINT-CHARLES et al., 2012). Men frequently ponder their decisions on the adoption of an innovation, preferably due to their economic benefits and contribution to family income (PHIRI et al., 2004), while women's decisions are based on risk perception and vulnerabilities, leading to preventive behaviour in healthcare (MERTENS et al., 2005, 2017) and adaptation to environmental and climate change (JIN; WANG; GAO, 2015).

Age, education, and experience in farming activity are widely recognised as human resource variables that can affect decisions in the adoption process (PROKOPY et al., 2008). For example, an increase in age may negatively correlate with technological change; the older the farmers are, the less prone they are to an eventual risk, and the more they resist a new practice (KABII; HORWITZ, 2006). However, other authors showed that more experienced farmers tend to be more efficient in incorporating new technologies and have a higher chance of understanding the benefits of agricultural innovations (LEBLANC et al., 2020). Additionally, farmers with higher educational levels tend to have a higher probability of adopting agricultural technologies that demand advanced technical abilities (BAUMGARTGETZ; PROKOPY; FLORESS, 2012).

Farmers' participation in associations, commissions, councils, and other decision-making spaces can make innovation more sustainable (BODIN; CRONA, 2008; OSTROM, 2000). The legitimacy of farmers' participation may favour more efficient planning and management of irrigation systems and increase farmers' perceptions of the benefits of innovations, as in the case of AWD (FULAZZAKY, 2017; PALIS et al., 2017).

\subsubsection{CHARACTERISTICS OF THE PRODUCTIVE SYSTEM}

The size of the farm and its multi-functionality, that is, the diversification of income-generating activities beyond agriculture, such as materials provision, production services, or animal husbandry and commercialisation, may favour the perception of benefits and the adoption of agricultural innovations (CASWELL et al., 2001; MANSON et al., 2014). The availability of financing options also positively influences the adoption process because access to funds allows increased capacity to experiment with a new practice. Another important factor relates to production expenses since some methods demand less labour and input during production or are more water-efficient, reducing the total production cost (PROKOPY et al., 2008).

\subsubsection{FORMAL AND INFORMAL COMMUNICATION CHANNELS}

Rogers (2003) defines a communication channel as the means through which messages are transmitted from one individual to another. Channels can influence individual perception because they reduce uncertainty on a given innovation, favouring its adoption. Communication may follow formal channels through interpersonal relationships, such as mass media or informal channels (MERTENS et al., 2017). Mass media includes radio, television, newspapers, and the internet, with the potential to reach a broad audience and spread relevant information for agricultural practices. Interpersonal communication relationships usually contribute to more than the dissemination of information since transmitted messages are discussed and interpreted according to the individual's social and cultural contexts (VALENTE; FOSADOS, 2006). 
Interpersonal communication patterns are often different between men and women. Discussion of health issues and socio-environmental themes tend to form dissemination pathways that connect preferably people of the same gender (BURGOS; MERTENS, 2017; TRIANA et al., 2016). However, relationships between men and women are essential for adopting sustainable practices that require collective implementation in homes or family groups (MERTENS; SAINT-CHARLES; MERGLER, 2012).

\section{METHODOLOGY}

\subsection{MODEL OF ANALYSIS}

Based on the revision of the main groups of factors presented above, Figure 1 illustrates the framework designed to analyse farmers' perception about AWD's multidimensional properties (economic, environmental, and health), as well as characteristics of farmers, of the productive system, and of communication channels, that can be associated with the perception of AWD benefits

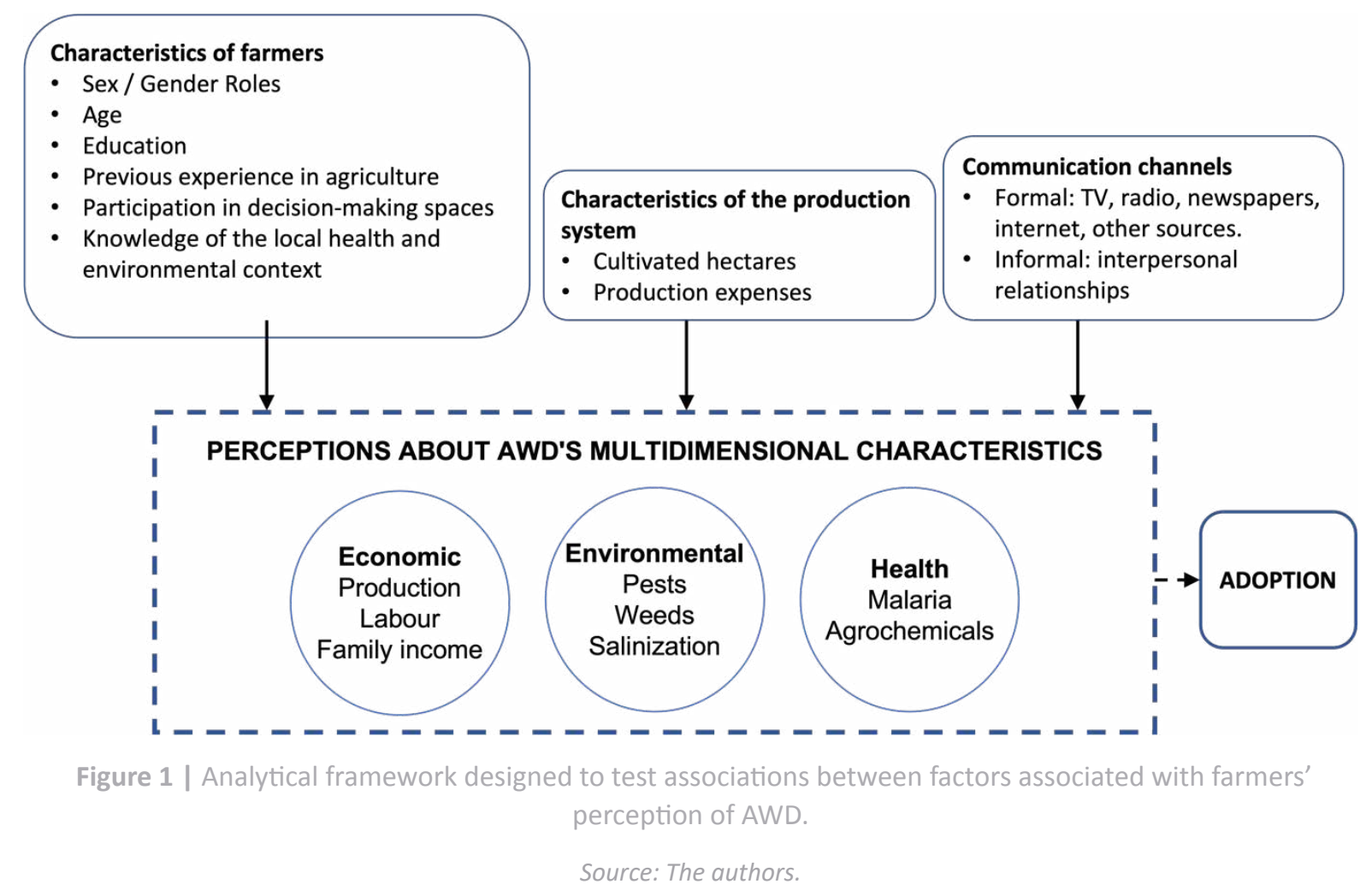

\subsection{AREA OF STUDY}

The area studied is the Jequetepeque river basin, on the northern coast of Peru and approximately $645 \mathrm{~km}$ from the capital Lima. The crucialmost important rice production areas are located in the Jequetepeque Valley, in the lower part of the basin, from the Gallito Ciego Dam to the river mouth into the sea (Figure 2). The valley has an area of approximately 227,000 hectares (32.5\% of the basin), of which 42,800 are arable. In 2017, the resident population was 181,315 inhabitants, living both in urban areas $(91.7 \%)$ and in rural areas $(8.3 \%)$ (INEI, 2018). This region is a hyper-arid zone characterised by low rainfall and high rates of evaporation. The climate is predominantly hot and dry, with an average annual rainfall of $150 \mathrm{~mm}$ and an average annual temperature of $24^{\circ} \mathrm{C}$ (PERU, 2016). Therefore, largescale agriculture is highly dependent on irrigation infrastructure and proper management for water distribution and use. 


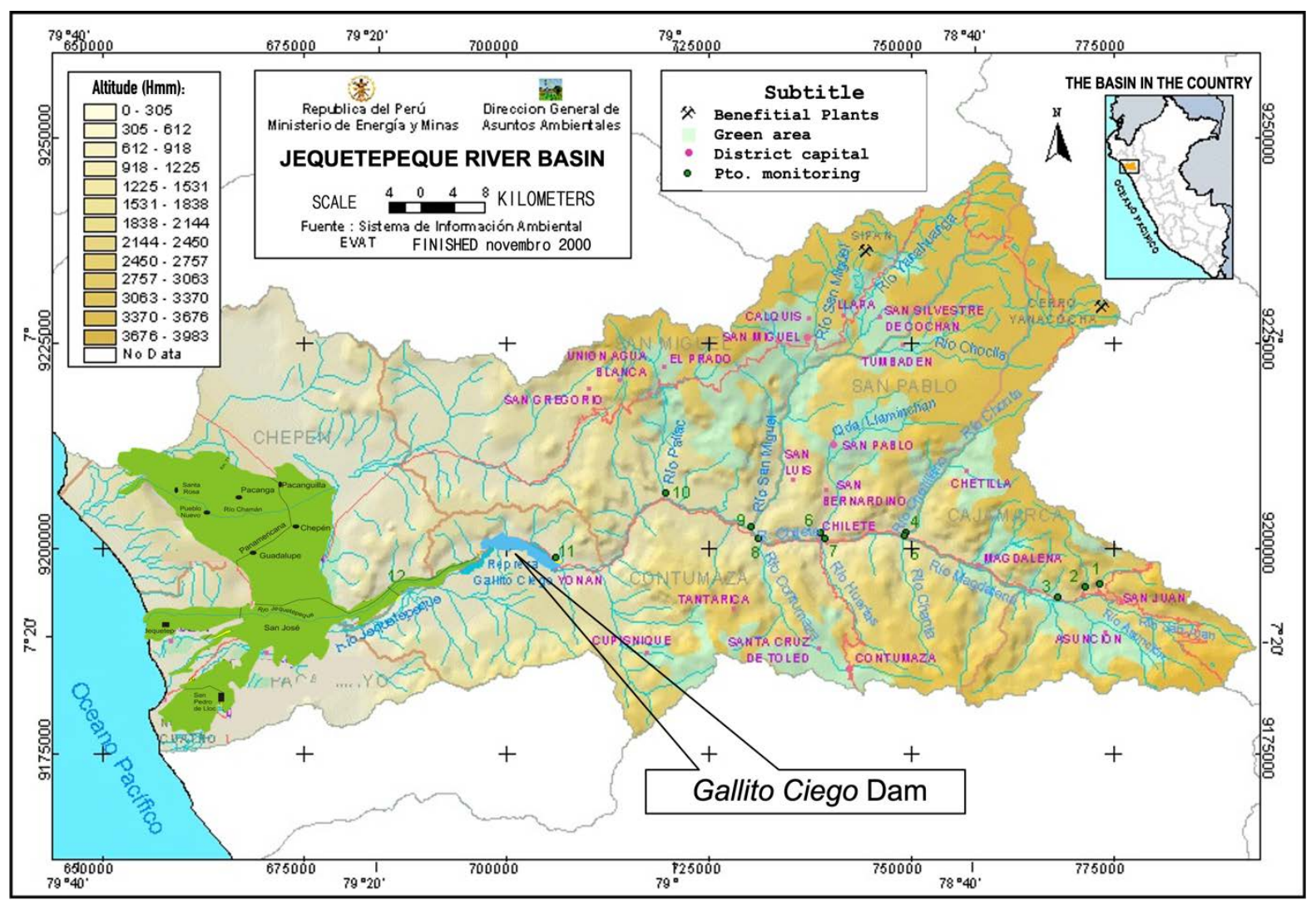

Figure 2 | Jequetepeque river basin highlights the Gallito Ciego dam and the Jequetepeque Valley (green area).

Source: (PERU, 2000) (adapted).

The valley's farmers are organised into different collective water management bodies. The main one is the Junta de Usuarios del Agua del Valle del Jequetepeque (JUAVJ), which brings together a total of 15,072 registered farmers. JUAVJ is a non-profit institution that operates and maintains the valley's hydraulic infrastructure. It manages water in a decentralised manner, through 14 Irrigation Commissions, responsible, in turn, for a series of hydraulic sectors, subdivided into Irrigation Committees, which organise the distribution of water to producer lots (GUERRERO-PADILLA, 2015; HUAMANCHUMO et al., 2008).

\subsection{STUDY POPULATION}

A sample for the study population was defined based on data provided by JUAVJ on the total number of farmers of legal age, registered as users of irrigation water and residing in the lower part of the Jequetepeque river basin (10,072 farmers). This calculation used the random sampling formula for proportions, considering a $95 \%$ confidence level and a $10 \%$ non-response rate. Thus, the approximate sample of the study population was 412 farmers. Then, a distribution, proportional to the strata size, that is, the population of each of the 14 Irrigation Commissions of Vale do Jequetepeque, was performed.

Within the ethical considerations of the project, a significant collective event was held with the participation of JUAVJ and its associated farmers. On that occasion, the different phases of the research were presented, including the experimental stages, where producers were informed about the benefits and possible difficulties of applying AWD and were able to use it to allocate parcels of their cultivation areas to the study. They were also informed about the stages of interviews, which the identified project team would conduct, considering voluntary participation, with prior informed consent from each producer and the anonymity of the information provided, to safeguard the safety and dignity of the participants. 
Thus, during June and July 2014, semi-structured interviews were conducted to apply a questionnaire to a total of 372 farmers, of which 53 were discarded for containing incomplete data, resulting in a final sample of 319 farmers across the valley.

\subsection{VARIABLES}

Data were collected on the three groups of factors defined in the analytical framework (Figure 1):

I. Characteristics of agricultural producers: sociodemographic data (sex, age group, education, and years of experience in rice farming), participation in collective water management organisations (JUAVJ and Irrigation Committees) and knowledge about transmission aspects and prevention of malaria, differentiating between participants who are unaware of the subject, those who only know one part (transmission or prevention) and those who know both aspects;

II. Characteristics of the production system, including the size of the cultivated area (in hectares) and expenses with labour and purchase of inputs (fertilisers and pesticides). The data collected refer to the 2013-2014 harvest;

III. Communication channels used to obtain information on the themes of agriculture and health, namely: formal, referring to the use of mass media (television, radio, newspapers, and internet) and informal, referring to interpersonal communication networks, mapped from the identification of the people with whom the participants declared they had talked about each topic. Respondents were able to mention as many people as they wanted. Both discussion networks (on agriculture or health) were characterised according to their size (number of people the participant talked to), gender composition (number of women/men they spoke to) and family composition (number of people from the family or outside the family with whom he said). Individuals outside the family (non-relatives) could be neighbours, friends, co-workers, agricultural technicians, health professionals, among others.

\subsection{THE MULTIDIMENSIONALCHARACTERISTICS OF AWD ANDTHE CONSTRUCTION OF THE PERCEIVED BENEFITS INDEX}

Participants' perception of the benefits and risks of adopting AWD was analysed using the question, "In your opinion, please indicate, among the options below, how AWD can affect the cultivation of rice on your property". A list of eight aspects was presented to the participant: (ec) economic, including rice production (ha), family income and employed labour; (en) environmental, referring to soil salinisation, the presence of pests and the appearance of weeds; and (h) health, referring to the occurrence of malaria and the use of pesticides. For each aspect, the participant indicated whether AWD could "benefit", "harm", "be indifferent", or "do not know how to give an opinion".

Individual responses were used to build a Perceived Benefits Index. For each aspect presented, the answers were scored as follows: zero, one or two points, when the participant identified, respectively, losses, lack of effect/could not give an opinion or benefits associated with the adoption of AWD. The points attributed to each characteristic were added up; the participants were divided into two groups, with predominantly negative (between 0-8 points) or positive (between 9-16 points) perceptions regarding the effects of adopting AWD. 


\subsection{STATISTICAL ANALYSIS}

Descriptive statistical analyses include frequency distributions, means, and ranges. Data were disaggregated by sex to identify possible differences between men and women in the study population (Chi-square or t-Student tests). The Perception of Benefits Index was integrated into bivariate logistic regression models to verify possible associations between the factors of the three groups analysed and the perception of benefits on AWD (HOSMER; LEMESHOW, 2000).

\section{RESULTS}

\subsection{THE FARMERS OF THE JEQUETEPEQUE VALLEY}

Table 1 presents data on the characteristics of the study participants, which totalled 287 men and 32 women, and the productive system. The age of respondents ranged between 21 and 90 years old, with an elevated average age of 59. More than half of the participants (65.9\%) have a level of education between primary and secondary, with an average of seven years of total duration informal studies. The time spent on rice farming is, on average, 26 years, with men having significantly more years of experience than women $(p=0.0004)$.

Regarding participation in collective water management entities, farmers participate, in more significant numbers, in local Irrigation Committees (56.4\%), compared to the regional organisation of Vale do Jequetepeque (JUAVJ) (39.5\%). Just over half of the study participants (50.8\%) are aware of the transmission and prevention of malaria, with only $9 \%$ of women unaware of the subject, against $22 \%$ of men. Finally, $52 \%$ of participants have a predominantly positive perception of the effects of adopting AWD. There is no significant difference between the groups of men and women.

Participants cultivated an average of 4.4 hectares in the 2013/2014 harvest, with wide variation (1-43 hectares). Men cultivate, on average, land significantly more extensive than women $(p=0.0207)$. Most participants reported having expenses with the purchase of fertilisers $(73 \%)$, pesticides $(72.7 \%)$ or with the payment of labour (71.8\%).

Table 1 | Frequency distribution of characteristics of farmers and production system, knowledge about malaria and perceptions of benefits of AWD for rice cultivation.

\begin{tabular}{cccc}
\hline & Total (\%) & Men (\%) & Women (\%) \\
\hline Age & & & 3,1 \\
$31-30$ & 2,8 & 2,8 & 3,1 \\
$41-50$ & 7,2 & 7,7 & 25,0 \\
$51-60$ & 15,7 & 14,6 & 34,4 \\
$61-70$ & 27,0 & 26,1 & 6,3 \\
$71-80$ & 26,6 & 28,9 & 25,0 \\
$81-90$ & 16,6 & 15,7 & 3,1 \\
Education (in years) & 4,1 & 4,2 & 43,8 \\
Primary (0-5) & & & 28,1 \\
Secondary (6-10) & 40,8 & 40,5 & 28,1 \\
Undergraduate (11-15) & 25,1 & 24,7 & 0
\end{tabular}




\begin{tabular}{|c|c|c|c|}
\hline & Total (\%) & Men (\%) & Women (\%) \\
\hline \multicolumn{4}{|l|}{ Experience in farming (years) } \\
\hline $1-10$ & 19,4 & 17,1 & 40,6 \\
\hline $11-20$ & 24,5 & 25,4 & 15,6 \\
\hline $21-30$ & 30,4 & 32,1 & 15,6 \\
\hline $31-40$ & 10,0 & 9,1 & 18,8 \\
\hline $41-50$ & 7,2 & 7,3 & 6,3 \\
\hline $51-60$ & 6,0 & 6,6 & 0,0 \\
\hline $61-70$ & 2,2 & 2,4 & 0,0 \\
\hline $71-80$ & 0,3 & 0,0 & 3,1 \\
\hline \multicolumn{4}{|l|}{ Participation in water management* } \\
\hline JUAVJ & 39,5 & 40,1 & 34,4 \\
\hline Irrigation Committees & 56,4 & 57,1 & 50,0 \\
\hline \multicolumn{4}{|c|}{ Knowledge about malaria transmission and prevention } \\
\hline Doesn't know & 21,3 & 22,6 & 9,4 \\
\hline Knows one aspect & 27,9 & 28,2 & 25,0 \\
\hline Knows both aspects & 50,8 & 49,1 & 65,6 \\
\hline \multicolumn{4}{|l|}{ Perceived benefits of AWD } \\
\hline Perceives little benefit & 48,0 & 48,4 & 43,8 \\
\hline Perceives benefits & 52,0 & 51,6 & 56,3 \\
\hline \multicolumn{4}{|l|}{ Total of cultivated hectares(ha)** } \\
\hline Average / SD / Interval & $4,4 / 5,2$ / 0-43 & $4,6 / 5,4 / 0-43$ & $2,4 / 1,6 / 0,5-5,5$ \\
\hline \multicolumn{4}{|l|}{ Production costs } \\
\hline Purchase of fertilisers & 73,0 & 72,8 & 75,0 \\
\hline Purchase of pesticides & 72,7 & 72,5 & 75,0 \\
\hline Labor & 71,8 & 71,8 & 71,9 \\
\hline
\end{tabular}

* Chi-Square $(p=0,0004) ; * *$ T-test $(p=0,0207)$

Source: Made by the authors (field research data).

Table 2(a) presents the frequencies of use, by the participants, of mass media to obtain information on themes related to agricultural activity and health. A little more than half of the participants use television (52.4\%) and radio (50.8\%) to obtain information about agriculture. Men use the radio at a significantly higher frequency (53\%) than women (31.3\%). Few respondents use newspapers (8.5\%) and the Internet (3.1\%). Other sources of information were indicated by $31 \%$ of the study participants, namely: information provided by the various irrigation commissions, materials distributed by other entities of the local government, JUAVJ, agro-industrial companies (Bayer, Farmex, Tecuse) and acquisition of farm inputs. About the topic of health, almost three quarters of the participants use television as their main source of information (71.5\%). In second and third place are the radio (23.5\%) and other sources of information (20.7\%). The latter are offered during consultations at health clinics and centres, in pharmacies, in Municipal Health Social Insurance offices, in children's schools, by the Ministry of Health, in health magazines and books offered by doctors and in churches. The use of newspapers and the internet is less frequent: only $13.5 \%$ and $3.1 \%$ of participants consult them, the latter being used only by men. 
Table 2 | Use of (a) formal and (b) informal communication channels to obtain information on agriculture and health.

\begin{tabular}{|c|c|c|c|c|c|c|c|}
\hline \multicolumn{8}{|c|}{ (a) Formal channels } \\
\hline & \multicolumn{2}{|c|}{ Total (\%) } & \multicolumn{3}{|c|}{ Men (\%) } & \multicolumn{2}{|c|}{ Women (\%) } \\
\hline \multicolumn{8}{|l|}{ Agriculture } \\
\hline TV & \multicolumn{2}{|c|}{52,4} & \multicolumn{2}{|r|}{52,3} & \multicolumn{3}{|c|}{53,1} \\
\hline Radio* & \multicolumn{2}{|c|}{50,8} & \multicolumn{2}{|r|}{53,0} & \multicolumn{3}{|c|}{31,3} \\
\hline Newspapers & \multicolumn{2}{|c|}{8,5} & \multicolumn{2}{|r|}{8,7} & \multicolumn{3}{|c|}{6,3} \\
\hline Internet & \multicolumn{2}{|c|}{3,1} & \multicolumn{2}{|r|}{3,5} & \multicolumn{3}{|c|}{0,0} \\
\hline Other sources & \multicolumn{2}{|c|}{31,0} & \multicolumn{2}{|r|}{31,4} & \multicolumn{3}{|c|}{28,1} \\
\hline \multicolumn{8}{|l|}{ Health } \\
\hline TV & \multicolumn{2}{|c|}{71,5} & \multicolumn{2}{|r|}{70,4} & \multicolumn{3}{|c|}{81,3} \\
\hline Radio* & \multicolumn{2}{|c|}{23,5} & \multicolumn{2}{|r|}{24,4} & \multicolumn{3}{|c|}{15,5} \\
\hline Newspapers & \multicolumn{2}{|c|}{13,5} & \multicolumn{2}{|r|}{13,2} & \multicolumn{3}{|c|}{15,6} \\
\hline Internet & \multicolumn{2}{|c|}{3,1} & & 3,5 & & 0,0 & \\
\hline Other sources & 20,7 & & & 20,6 & & 21,9 & \\
\hline & & Inforn & channels & & & & \\
\hline & & Total & & Me & & Wor & \\
\hline $\begin{array}{r}\text { Interpersonal discussion } \\
\text { on agriculture }\end{array}$ & Average & $S D$ & Interval & Average & $S D$ & Average & $S D$ \\
\hline Number of individuals & 3,8 & 2,2 & $0-11$ & 3,9 & 2,3 & 3,3 & 1,6 \\
\hline Number of men** & 3,6 & 2,2 & $0-11$ & 3,7 & 2,2 & 2,8 & 1,6 \\
\hline Number of women $* * *$ & 0,2 & 0,5 & $0-4$ & 0,2 & 0,4 & 0,6 & 0,9 \\
\hline Number of relatives & 0,5 & 0,8 & $0-4$ & 0,4 & 0,8 & 0,6 & 0,8 \\
\hline Number of non-relatives & 3,3 & 2,2 & $0-11$ & 3,4 & 2,2 & 2,2 & 1,7 \\
\hline $\begin{array}{r}\text { Interpersonal discussion } \\
\text { on health }\end{array}$ & Average & $S D$ & Interval & Average & $S D$ & Average & $S D$ \\
\hline Number of individuals & 2,4 & 1,5 & $0-6$ & 2,4 & 1,6 & 2,2 & 0,9 \\
\hline Number of men & 1,6 & 1,2 & $0-6$ & 1,6 & 1,3 & 1,5 & 1,0 \\
\hline Number of women & 0,8 & 0,9 & $0-4$ & 0,8 & 0,9 & 0,7 & 0,7 \\
\hline Number of relatives & 0,9 & 1,2 & $0-6$ & 0,9 & 1,3 & 1,1 & 1,1 \\
\hline Number of non-relatives & 1,4 & 1,3 & $0-6$ & 1,5 & 1,4 & 1,1 & 0,2 \\
\hline
\end{tabular}

*Chi-square $(p<0,05)$; **Anova $(p<0,05)$; *** Anova $(p<0,0001)$

Source: Made by the authors (field research data).

Table 2(b) presents the interpersonal communication data on agriculture and health between men and women participating in the study. The number of individuals with whom men and women talk about agriculture is similar, on average 3.9 people and 3.3 people, respectively. Both men and women converse, on average, with more men than women. However, men talk significantly more than women with other men, while women speak considerably more than men with other women. The discussion about agricultural practices occurs more frequently with people outside the family nucleus, on average 3.3 than with people from the same family, on average 0.5 .

On average, men and women talk to similar people on health, and both preferentially speak to men about the subject. Men talk about the health issue preferably with individuals outside the family, while women talk in the same proportions with people outside the family and with family members. 


\subsection{FARMERS' PERCEPTION OF THE BENEFITS OF ADOPTING AWD FOR RICE CULTIVATION}

Figure 3 shows the percentages of individuals who consider that AWD brings benefits, harms or is indifferent about economic (ec), environmental (en) and health (h) aspects of rice cultivation. The characteristic of AWD most often considered advantageous is related to reducing the occurrence of pests (65\%). Second, many participants (59\%) think it is positive that AWD allows for a reduction in the consumption of agrochemicals. The third most mentioned benefit (44\%) concerns the increase in rice production. AWD aspects considered most harmful for rice cultivation are weed control (66\%) and the need to employ more labour (37\%). This is because periods of drought provide the appearance of opportunistic plants that compete with rice for soil nutrients, bringing losses to production and whose removal requires considerable labour for manual weeding. Many participants (63\%) did not identify benefits or harms in the application of AWD about malaria incidence, probably because they were not aware that drought interrupts the larval cycle of mosquitoes that are vectors of the disease. The role of applying AWD to reduce soil salinisation was also not recognised by most participants.

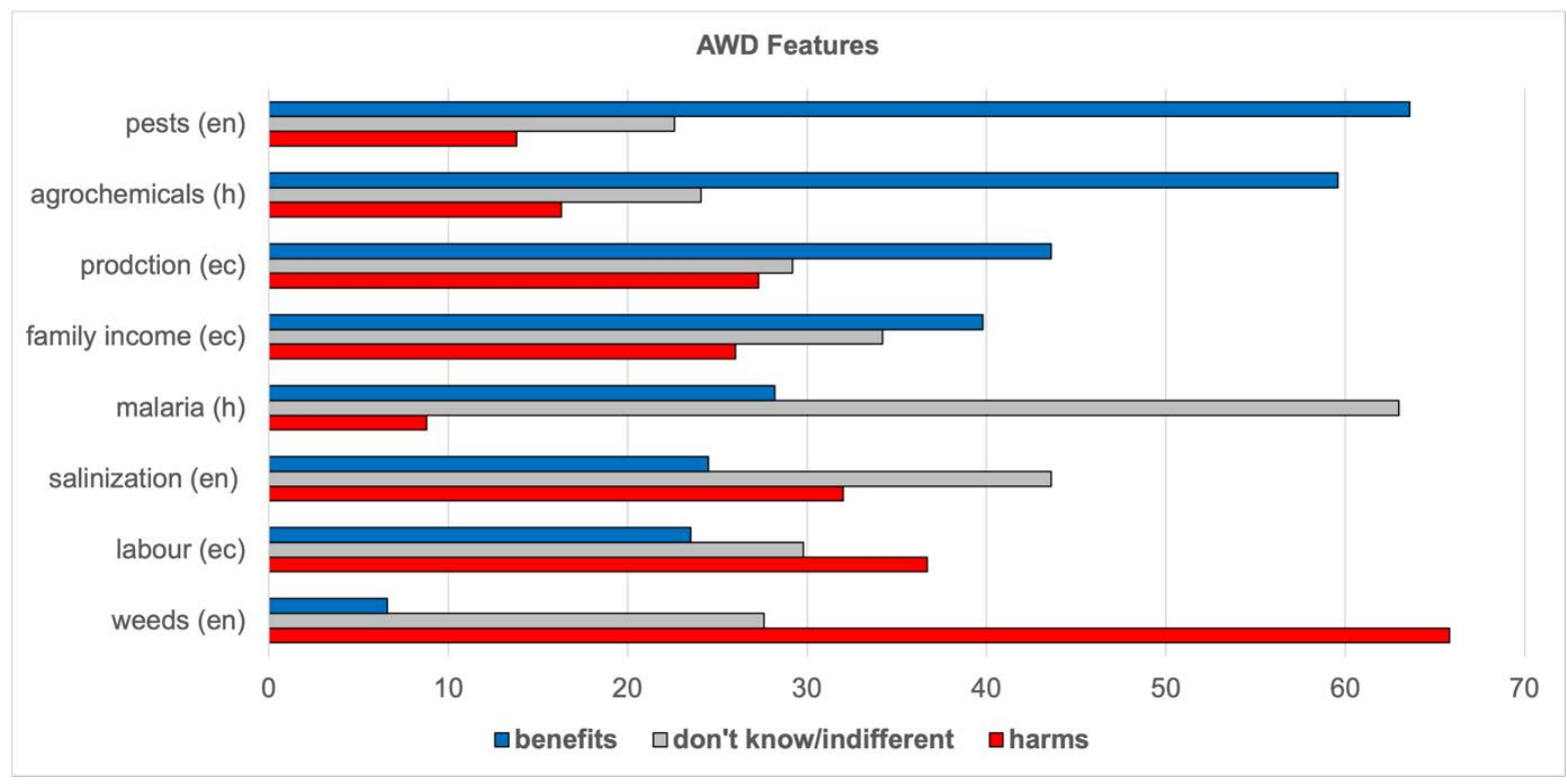

Figure 3 | Percentages of participants who consider that AWD brings benefits, harms or is indifferent/does not know how to give an opinion regarding environmental (en), economic (ec) and health (h) aspects.

Source: Made by the authors (field research data).

\subsection{FACTORS ASSOCIATED WITH PERCEIVED BENEFITS OF USING AWD FOR RICE CULTIVATION}

Table 3 presents the results of the bivariate logistic regressions that show the probability of association between the characteristics of farmers and production systems, the channels of communication and the predominantly positive perception of the effects of AWD on rice cultivation. Previous experience in agriculture and participation in the two water management entities were associated with a greater likelihood of recognising benefits from AWD. Expenses with labour, the purchase of fertilisers and pesticides, and the level of knowledge about malaria transmission and prevention were also associated with a preferentially beneficial perception of AWD for rice cultivation. The other variables did not show a significant association. 
Table 3 | Bivariate logistic regressions show the probability of association between the characteristics of the producers and the productive system, the communication channels, and the predominantly positive perception of AWD for rice cultivation.

\begin{tabular}{|c|c|c|}
\hline Bivariate Models & odd ratios & $p$ \\
\hline \multicolumn{3}{|c|}{ Farmers' characteristics } \\
\hline Sex & 0,828 & 0,6154 \\
\hline Age & 1,004 & 0,6342 \\
\hline Education & 1,009 & 0,7246 \\
\hline Experience in agriculture & 1,025 & 0,0150 \\
\hline Participation in JUAVJ & 2,867 & $<0,0001$ \\
\hline Participation in Irrigation Committees & 2,457 & 0,0001 \\
\hline Knowledge about malaria & 1,807 & $<0,0001$ \\
\hline \multicolumn{3}{|c|}{ Productive systems' characteristics } \\
\hline Total of cultivated hectares & 0,974 & 0,2551 \\
\hline Purchase of fertilisers & 2,444 & 0,0006 \\
\hline Purchase of pesticides & 2,514 & 0,0004 \\
\hline Labour & 2,393 & 0,0007 \\
\hline \multicolumn{3}{|c|}{ Formal communication channels on agriculture } \\
\hline TV & 0,956 & 0,8395 \\
\hline Radio & 0,805 & 0,3352 \\
\hline Newspapers & 0,608 & 0,2231 \\
\hline Internet & 0,605 & 0,4432 \\
\hline Other sources & 0,970 & 0,9003 \\
\hline \multicolumn{3}{|c|}{ Formal communication channels on health } \\
\hline TV & 1,229 & 0,4054 \\
\hline Radio & 0,755 & 0,2878 \\
\hline Newspapers & 2,698 & 0,0059 \\
\hline Internet & 0,605 & 0,4432 \\
\hline Other sources & 0,525 & 0,0221 \\
\hline \multicolumn{3}{|c|}{ Interpersonal discussion on agriculture } \\
\hline Number of individuals & 1,150 & 0,0082 \\
\hline Number of men & 1,151 & 0,0087 \\
\hline Number of women & 1,028 & 0,9007 \\
\hline Number of relatives & 0,860 & 0,3065 \\
\hline Number of non-relatives & 1,175 & 0,0032 \\
\hline \multicolumn{3}{|c|}{ Interpersonal discussion on health } \\
\hline Number of individuals & 1,088 & 0,2597 \\
\hline Number of men & 1,059 & 0,5238 \\
\hline Number of women & 1,141 & 0,3060 \\
\hline Number of relatives & 0,813 & 0,0253 \\
\hline Number of non-relatives & 1,355 & 0,0008 \\
\hline
\end{tabular}


None of the formal means of communication used to obtain information about agriculture was associated with participants' perception of the benefits or harms of adopting AWD. The use of newspapers and other sources of data on the topic of health, on the other hand, was significantly associated with the perception of benefits in using the practice. The number of individuals, men, and people outside the family with whom the participants discussed agriculture was positively associated with the perception of the benefits of AWD. The greater the number of members outside the family with whom one talks about health, the greater the probability that the farmer will consider that AWD has advantages for rice cultivation. On the contrary, participants who speak to family members about health are less likely to think that the use of AWD is preferentially beneficial for rice cultivation.

\section{DISCUSSION}

This article demonstrates that producers recognise the interactions between AWD's economic, environmental and health aspects but consider the financial aspects of the production process primarily when evaluating the benefits and losses potentially brought by the adoption of the technique. Among the characteristics of AWD considered the most beneficial (pest control, reduction of agrochemicals, productivity, and family income), the first two have implications for environmental aspects, improving pest control and human health through more effective management of agrochemicals. The last two most beneficial characteristics address essentially economic elements, such as increased production and family income. However, the economic benefits of AWD gain relevance as both the occurrence of pests and the use of agrochemicals interfere with production costs. Similarly, producers who declared they had expenses to purchase fertilisers, pesticides, and hiring labour also considered AWD predominantly brings advantages. Primarily among these producers, it is likely that the implementation of the practice, which reduces production expenses, is readily perceived as advantageous, as pointed out in previous studies (MUBEEN; JABRAN, 2019).

The two aspects of AWD considered most harmful to rice production also have economic implications for the producer. Crop field irrigation directly controls weeds in rice fields, which proliferate without the permanent layer of water (ISHFAQ et al., 2020). Thus, the change from the water-intensive regime to more aerobic cultivation may mean an increase in production costs, through the purchase and application of herbicides, but mainly through the hiring of additional labour, which was the second aspect of AWD considered more harmful to rice production.

This study showed that some sociodemographic characteristics were associated with the perception of benefits in applying AWD. Study participants who are more experienced in agriculture perceive more benefits from using AWD than farmers who have been working longer in rice cultivation. This result is compatible with other studies that showed that previous agricultural experience implies knowledge acquired over time and is essential in assessing technological innovations (LEBLANC et al., 2020).

Although knowledge about malaria is positively associated with a more favourable perception of AWD, more than $70 \%$ of producers did not identify combating the disease as a benefit explicitly associated with its adoption in rice crops. This result suggests that most producers have little knowledge about the reproductive cycle of vector mosquitoes and the role of AWDin interrupting this cycle. In addition, the farmers' observations and practical experiences with AWD, whether in their crops, in neighbours' plots or demonstration units, can make it challenging to understand the effects of the technique to reduce the risk of malaria transmission. Three factors can contribute to these difficulties: i) when AWD has applied alone in a small area, it may not be effective in significantly reducing adult mosquito populations, especially when neighbouring producers continue to keep their fields permanently flooded; ii) although the short periods without water in the crops are enough to eliminate the mosquito larvae, the efficiency of the technique in fighting malaria depends on the duration of the flooded periods, which, in cases of carelessness or lack of information by the producer, can allow the larval cycle to take place whenever it exceeds 8 days; and iii) during each phase of flooding in the rice fields, even those lasting less than 8 
days, producers observe the proliferation of mosquito larvae, raising doubts about the effectiveness of the technique. In all, these results suggest that information campaigns on malaria should not be limited to the field of health but rather explicitly reinforce the links between strict agricultural water control practices and its direct effects on reducing vector-borne diseases.

The results revealed essential aspects about the role of communication channels in agriculture and health issues among farmers in the valley. The perception of benefits from the use of AWD was not associated with using any of the mass media as information on agriculture. Previous research reveals the importance of communication campaigns to promote sustainable practices in agriculture and health (MERTENS et al., 2017). However, this result suggests that formal communication channels have not been used to disseminate information about the advantages of AWD for productive activity.

On the other hand, the results show an active interpersonal discussion about agriculture among the study participants. They suggest that information about the benefits of AWD can circulate among male farmers who talk about the topic. In addition, men speak about agriculture more often with people outside the family than with their relatives. In general, these discussions are associated with a perception of benefits in the use of AWD, indicating that interpersonal communication with neighbours, friends, and agricultural technicians, who provide periodic advice to farmers, has the potential to expand the process of disseminating information that can foster adoption of the technique. Finally, the participation of producers in collective water management entities in the valley was also associated with more favourable perceptions about AWD. These entities are collaborative spaces for meetings and events that favour information about agricultural innovations and a better understanding of the benefits of new practices (HUAMANCHUMO et al., 2008).

Newspapers, magazines, and health books accessed in health centres, pharmacies, and churches seem to represent means of disseminating information favourable to AWD use. They can be used to spread knowledge about health that is reflected in the agricultural production methods in the region. The association between the perception of benefits of AWD and the discussion about health with members outside the family reinforces the idea that information on health regarding the use of AWD may have circulated during medical consultations or visits to health centres. The reasons why conversations on health with family members are associated with a more excellent perception of damage in the use of AWD deserve to be investigated.

\section{CONCLUSION}

The results show the relevance of integrating a more detailed analysis of farmers' perceptions of AWD's environmental, social and health impacts and the characterisation of factors associated with a favourable perception of its use in rice fields. This integrated analysis allows understanding of the producers' most relevant aspects, potentially facilitating and slowing down the adoption process, and how the interactions between these factors form the perceptions that guide decision-making.

The study showed that producers prioritise both the direct and purely economic implications and their indirect economic implications, focusing on environmental and human health. Developing new actions to promote AWD that link environmental and health issues with the economic priorities of producers, so that they are capitalised on by privileged communication networks, channels, and spaces for debate on the themes of agriculture and health, appears as a promising strategy to contribute to the sustainability of rice production in the Jequetepeque Valley.

The information generated in this work contributes to knowledge about strategies to promote agricultural practices that save water, which reflect in economic gains and allow reducing the socio-environmental and health vulnerability of populations and can be used by new research in the Jequetepeque Valley and in different regions that present similar epidemiological challenges, in contexts of water scarcity, environmental changes and climate uncertainty. 


\section{ACKNOWLEDGMENTS}

We express our gratitude to the residents of the Jequetepeque Valley for their hospitality, participation, and collaboration in the fieldwork. We also thank the Pedro Miranda Project local coordinator, agronomist Luiz Ventura and the entire field team, and the General Director of Environmental Health at the Ministry of Health of Peru, Carmen Cruz. This work was funded by the International Development Research Center (IDRC) and the Coordination for the Improvement of Higher Education Personnel (Capes).

\section{REFERENCES}

ALAUDDIN, M. et al. Adoption of alternate wetting and drying (AWD) irrigation as a water-saving technology in Bangladesh: economic and environmental considerations. Land use Policy, v. 91, n. october 2019, p. 104430, 2020.

ALEN, J. M.; SANDER, B. O. The diverse benefits of Alternate Wetting and Drying (AWD). Los Baños, Philippines: 2019.

BALAINE, N. et al. Greenhouse Gases from Irrigated Rice Systems under Varying Severity of Alternate-Wetting and Drying Irrigation. Soil Science Society of America Journal, v. 83, n. 5, p. 1533-1541, 2019.

BAUMGART-GETZ, A.; PROKOPY, L. S.; FLORESS, K. Why farmers adopt best management practice in the United States: a meta-analysis of the adoption literature. Journal of Environmental Management, v. 96, n. 1, p. 17-25, 2012. Available at: https://doi.org/10.1016/j.jenvman.2011.10.006

BODIN, Ö.; CRONA, B. I. Management of Natural Resources at the Community Level: exploring the role of social capital and leadership in a rural fishing community. World Development, v. 36, n. 12, p. 2763-2779, 2008.

BURGOS, A.; MERTENS, F. Participatory management of community-based tourism: a network perspective. Community Development, v. 48, n. 4, p. 546-565, 2017.

CASWELL, M. et al. Adoption of Agricultural Production Practices: lessons learned from the U.S. Agricultural Economic Report, n. 792, p. 116, 2001.

CHÁVEZ, W. C. Evaluación Ambiental de la Iniciativa de Riego con Secas Intermitentes en el Cultivo de Arroz para el Control de la Malaria. 2007.

ENRIQUEZ, Y. et al. Disentangling Challenges to Scaling Alternate Wetting and Drying Technology for Rice Cultivation: distilling lessons from 20 years of experience in the Philippines. Frontiers in Sustainable Food Systems, v. 5, n. June, p. 1-16, 2021.

FULAZZAKY, M. A. Participation of farmers in irrigation water management in Indonesia: a review. Irrigation and Drainage, v. 66, n. 2, p. 182-91, 2017.

GIRALT, S. et al. The History of the El Niño: southern oscillation according to lacustrine and marine sediments. Contributions to Science, v. 3, n. 3, p. 343-353, 2007.

GORDON, L. J.; FINLAYSON, C. M.; FALKENMARK, M. Managing water in agriculture for food production and other ecosystem services. Agricultural Water Management, v. 97, n. 4, p. 512-519, 2010.

GUERRERO-PADILLA, A. M. Demanda hídrica y calidad de agua de uso agrícola de la cuenca del Río Jequetepeque, Perú. REBIOL - Revista Científica de la Facultad de Ciencias Biológicas, v. 35, n. 2, p. 5-18, 2015.

GUTHMANN, J. P. et al. Environmental factors as determinants of malaria risk. A descriptive study on the northern coast of Peru. Tropical Medicine \& International Health, v. 7, n. 6, p. 518-525, 2002.

HOSMER, D. W.; LEMESHOW, S. Applied logistic regression. 2. ed. Columbus, Ohio: 2000.

HUAMANCHUMO, J. et al. Developing capacity in water users organizations: the case of Peru. Irrigation and Drainage, v. 57, p. 300-310, 2008. 
HUMPHREYS, E. et al. Water Saving in Rice-Wheat Systems. Plant Production Science, v. 8, n. 3, p. 242-258, 2005.

IBARGÜEN, L. A. O. Situación epidemiológica de la malaria en el Perú. Boletín Epidemiológico del Perú, v. 28, SE 42, Lima. 2019.

INEI. Censos Nacionales 2017: XII de Población, VII de Vivienda y III de Comunidades Indígenas. 2018.

ISHFAQ, M. et al. Alternate wetting and drying: a water-saving and ecofriendly rice production system. Agricultural Water Management, v. 241, n. June, p. 106363, 2020.

JIN, J.; WANG, X.; GAO, Y. Gender differences in farmers' responses to climate change adaptation in Yongqiao District, China. Science of the Total Environment, v. 538, p. 942-948, 2015.

KABII, T.; HORWITZ, P. A review of landholder motivations and determinants for participation in conservation covenanting programmes. Environmental Conservation, v. 33, n. 1, p. 11-20, 2006.

KEISER, J.; UTZINGER, J.; SINGER, B. H. The potential of intermittent irrigation for increasing rice yields, lowering water consumption, reducing methane emissions, and controlling malaria in African rice fields. Journal of the American Mosquito Control Association, v. 18, n. 4, p. 329-340, 2002.

KIBRET, S. et al. Can water-level management reduce malaria mosquito abundance around large dams in subSaharan Africa? PLoS ONE, v. 13, n. 4, p. 1-12, 2018.

LEBLANC, G. et al. Profitability prospects, risk aversion and time preferences of soybean producers in the region of Santarém, Brazilian Amazon: perspectives for an ecological transition. Renewable Agriculture and Food Systems, 2020.

MACHER, J. C. S.; LUNA, E. F. R. Estudio Económico. Riego con secas intermitentes en el cultivo de arroz para el control vectorial de la malaria y una agricultura más sana y sostenible: escalamiento en el Valle de Jequetepeque. La Libertad. Estudio de Aproximación Ecosistémica. Lima: 2016.

MANSON, S. M. et al. Modeling the effect of social networks on adoption of multifunctional agriculture. Environmental Modelling \& Software, v. 75, p. 388-401, 2014.

MEIJER, S. S. et al. The role of knowledge, attitudes and perceptions in the uptake of agricultural and agroforestry innovations among smallholder farmers in sub-Saharan Africa. International Journal of Agricultural Sustainability, v. 13, n. 1, p. 40-54, 2015.

MERTENS, F. et al. Information sources, awareness and preventive health behaviors in a population at risk of Arsenic exposure: the role of gender and social networks. PLoS ONE, v. 12, n. 10, p. 1-14, 2017.

MERTENS, F. et al. Network approach for analyzing and promoting equity in participatory ecohealth research. EcoHealth, v. 2, n. 2, p. 113-126, 2005.

MERTENS, F.; SAINT-CHARLES, J.; MERGLER, D. Social communication network analysis of the role of participatory research in the adoption of new fish consumption behaviors. Social Science \& Medicine, v. 75, n. 4, p. 643-650, 2012.

MUBEEN, K.; JABRAN, K. Alternate Wetting and Drying System for Water Management in Rice. In: HASANUZZAMAN, M. (Org.). Agronomic Crops. Singapore: Springer, 2019. p. 101-110.

OSTROM, E. Reformulating the commons. Swiss Political Science Review, v. 6, n. 1, p. 29-52, 2000.

PALIS, F. G. et al. A multi-stakeholder partnership for the dissemination of alternate wetting and drying watersaving technology for rice farmers in the Philippines. AIMS Agriculture and Food, v. 2, n. 3, p. 290-309, 2017.

PERU. Cuenca del Rio Jequetepeque. 2000. Available at: http://www.minem.gob.pe/minem/archivos/file/ dgaam/publicaciones/evats/jequetepeque/JEQUET2.pdf. Accessed in: 20 ago. 2019.

PERU. El Perú y el Cambio Climático: tercera comunicación nacional del Perú a la Convención Marco de las Naciones Unidas sobre el Cambio Climático. Lima: 2016. 
PERU. El riego con secas intermitentes en el cultivo del arroz para el control vectorial de la malaria y una agricultura más sana y sostenible: escalamiento en el Valle Jequetepeque. Lima: 2012.

PERU. Plan de Implementación de la Estrategia de Riego con Secas Intermitentes en el Cultivo de Arroz para el Control Vectorial de la Malaria en Regiones Priorizadas del Perú. Lima: 2011.

PERU. Salud y Agricultura Sostenibles: un reto del futuro. Riego intermitente en el cultivo del arroz para el control vectorial de la Malaria en la costa norte peruana. Lima: 2002.

PHIRI, D. et al. Who is using the new technology? The association of wealth status and gender with the planting of improved tree fallows in Eastern Province, Zambia. Agricultural Systems, v. 79, n. 2, p. 131-144, 2004.

PROKOPY, L. S. et al. Determinants of agricultural best management practice adoption: evidence from the literature. Journal of Soil and Water Conservation, v. 63, n. 5, p. 300-311, 2008.

RODRÍGUEZ-MORATA, C. et al. The anomalous 2017 coastal El Niño event in Peru. Climate Dynamics, v. 52, n. 6, 2019.

ROGERS, E. M. Diffusion of Innovations. Thirded. New York: The Free Press, 2003. ISSN 0306-4603.

SAINT-CHARLES, J. et al. Diffusion of environmental health information: the role of sex and gender-differentiated pathways. In: What a Difference Sex and Gender Make: a gender, sex and health research casebook, p. 69-76, 2012.

TRIANA, D. R. R. et al. The Role of Gender in Chagas Disease Prevention and Control in Honduras: an analysis of communication and collaboration networks. EcoHealth, v. 13, n. 3, p. 535-548, 2016.

VALENTE, T. W.; FOSADOS, R. Diffusion of innovations and network segmentation: the part played by people in promoting health. Sexually transmitted diseases, v. 33, n. 7, p. S23-S31, 2006.

VÉLEZ, J. R. G. Análisis de la adherencia de la técnica de secas en el distrito de Pítipo: Campaña 2007 - 2008. Iniciativa de la Técnica de Riego con Secas Intermitentes en el cultivo de arroz para el control vectorial de la malaria región Lambayeque. 2008. 